\title{
Wilhelm Koppe en Josef Oberhauser versus de West-Duitse justitie: voorbeelden van een eerste vorm van revisionisme
}

Wilhelm Koppe et Josef Oberhauser face à la justice ouest-allemande : exemples d'une première forme de révisionnisme

Wilhelm Koppe and Josef Oberhauser versus West-German justice: two examples of a first type of revisionism

\section{Sila Cehreli}

Traducteur : Gorik de Henau

\section{(2) OpenEdition \\ 12 Journals}

\section{Édition électronique}

URL : https://journals.openedition.org/temoigner/4265

DOI : $10.4000 /$ temoigner.4265

ISSN : 2506-6390

Cet article est une traduction de :

Wilhelm Koppe et Josef Oberhauser face à la justice ouest-allemande : exemples d'une première

forme de révisionnisme - URL : https://journals.openedition.org/temoigner/4162 [fr]

Éditeur :

Éditions du Centre d'études et de documentation Mémoire d'Auschwitz, Éditions Kimé

Édition imprimée

Date de publication : 2 mai 2016

Pagination : $67-79$

ISSN : 2031-4183

Référence électronique

Sila Cehreli, «Wilhelm Koppe en Josef Oberhauser versus de West-Duitse justitie: voorbeelden van een eerste vorm van revisionisme», Témoigner. Entre histoire et mémoire [Online], 122 | 2016, Online op 30 septembre 2021, geraadpleegd op 03 février 2022. URL: http://journals.openedition.org/temoigner/ 4265 ; DOI: https://doi.org/10.4000/temoigner.4265 


\section{Wilhelm Koppe enJosef Oberhauser versus de West-Duitse justitie: voorbeelden van een eerste vorm van revisionisme}

$\rightarrow$ Sila Cehreli

Universiteit van Marmara
(1) Zie het proces-verbaal van het verhoor van Wilhelm Koppe in Bonn op 2 en 3 februari 1960 (Barch 162/3243, bladen 129-167).

(2) Barch 162/3243, bladen 170-172.

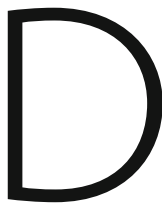

e nazimisdadigers dievanaf eind jaren vijftig met de West-Duitse justitie te maken kregen, hebben vaak hun toevlucht genomen tot strategieën om zichzelf vrij te pleiten. Tegenover de onderzoeksrechters trachtten ze de feiten over de Joodse genocide te manipuleren en zelfs te verdoezelen. Er waren toen weinig overlevenden die naar voren kwamen en het tijdperk van de historici en de herinneringsdebatten was nog niet aangebroken.

Een eerste voorbeeld van zo'n moeilijke zaak draait rond de vraag wie de belangrijkste verantwoordelijke is voor de Endlösung in de Rijksgouw Wartheland (afgekort Warthegau). Wie gaf de bevelen en instructies door aan de speciale eenheid in Chełmno, het $S S$-Sonderkommando Kulmhof? Uit een rapport dat procureur Dietrich Zeug op 12 oktober 1961 richtte aan de Zentrale Stelle (Centraal Bureau van de Juridische Overheidsadministraties voor Onderzoek naar de Nationaalsocialistische Misdaden) in Ludwigsburg blijkt duidelijk hoe gecompliceerd die vraag wel is.

Als waarnemer van het parket in Frankfurt had procureur D. Zeug van begin april tot augustus 1961 in Israël het proces tegen Adolf Eichmann gevolgd. Tijdens zijn verblijf in Jeruzalem werd hij herhaaldelijk door advocaat Dieter W. aangesproken over Wilhelm Koppe, de opperbevelhebber van de SS en de politie in de Warthegau. Die laatste was, onder de naam Wilhelm Lohmann ${ }^{1}$, op 31 januari $1960^{2}$ gearresteerd en hij wachtte op het begin van zijn proces. De zoon van Koppe, een collega van advocaat Dieter W., bereidde zich voor om zijn vader te verdedigen op dat proces, dat zou gaan over de misdaden in Chełmno.

Tijdens een van zijn verhoren beweerde Wilhelm Koppe dat het om een wettelijke naamsverandering ging. Die had hij in april 1945 in Berlijn doorgevoerd om zijn gezin te beschermen; de 'ramp', meer bepaald de nederlaag van het Derde Rijk, was toen onafwendbaar geworden. De procureur die het verhoor leidde, stipte evenwel aan dat op de nieuwe identiteitskaart ook datum en geboorteplaats van de verdachte waren vervalst, wat in het geval van een wettelijke naamsverandering niet had mogen gebeuren. Tegen dit argument verdedigde W. Koppe zich door de nadruk te leggen op 
Wilhelm Koppe en Josef Oberhauser versus de WestDuitse justitie: voorbeelden van een eerste vorm van revisionisme (vervolg)
(3) Odilo Globocnik was hoofd van de SS en de politie in Lublin, en leidde Aktion Reinhard, dat wil zeggen de terechtstelling van Joden in de kampen Bełżec, Sobibór en Treblinka.

(4) Zie de officiële verklaring van Dietrich Zeug (Barch 162/3247, bladen 759-761).

(5) Zie het proces-verbaal van het verhoor van Wilhelm Koppe in Bonn op 2 en 3 februari 1960.

(6) Dr. Brandt maakte deel uit van de persoonlijke staf van de Reichsführer-SS.

(7) Enst Damzog was inspecteur van de Sicherheitspolizei en de veiligheidsdienst in de Warthegau. de chaotische toestand die in het voorjaar van 1945 heerste op het Reichsministerium van Binnenlandse Zaken, waar hij zijn aanvraag had ingediend.

In zijn officiële rapport aan de Zentrale Stelle in Ludwigsburg schrijft Dietrich Zeug zijn mening neer over de briefwisseling tussen advocaat Dieter W. en de zoon van W. Koppe. Ze was hem toegestuurd door de onderzoeksrechter van de rechtbank van eerste aanleg in Bonn, die met de voorbereiding van het proces was belast. Daarin valt te lezen hoe advocaat Dieter W. aan Eichmann vroeg of de opperbevelhebber van de SS en de politie in de Warthegau betrokken was geweest bij de misdaden in Chełmno. Eichmann zou, nog steeds volgens die briefwisseling, hebben geantwoord dat hij daarvan helemaal niet op de hoogte was.

In zijn rapport weerlegde procureur Zeug nochtans de inlichting die leek te wijzen op de onschuld van W. Koppe; daarvoor baseerde hij zich op zijn eigen vooronderzoek naar de kampen in Bełżec, Sobibór en Treblinka. Na het bestuderen van een honderdtal getuigenissen en talrijke documenten uit zowel West-Duitse als internationale archieven, concludeerde de procureur dat er geen enkele aanwijzing bestond als zou ook het kamp Chełmno tot de verantwoordelijkheid van Odilo Globocnik ${ }^{3}$ hebben behoord; die hypothese was door de zoon van Wilhelm Koppe geopperd als onderdeel van de strategie om de onschuld van zijn vader te bewijzen. Maar volgens het onderzoek van D. Zeug waren Adolf Eichmann en afdeling IVB4 van het Reichssicherheitshauptamt (RSHA) in geringe mate betrokken bij Aktion Reinhard, wat het voor Eichmann onmogelijk maakte om inlichtingen te verschaffen betreffende de functie die Wilhelm Koppe tijdens de oorlogsjaren uitoefende. ${ }^{4}$ Die laatste ontkende tijdens de verhoren zijn betrokkenheid bij de terechtstelling van de Joden in Chełmno; hij beweerde dat hij alleen instond voor het opvangen van de Duitse immigranten in de Warthegau. ${ }^{5}$ Toch loochende hij niet dat er een genocidebeleid werd gevoerd. Integendeel, voor zijn verhoor stelde hij een relaas op waarin hij dat genocidebeleid en zijn zogenaamde onschuld in één adem noemde.

Volgens datzelfde relaas zou W. Koppe in 1940 of 1941 hebben gehoord hoe een Berlijnse commissaris de opdracht had gekregen om de Joden met behulp van een commando uit de Warthegau te 'evacueren' - een term die toen al op fysieke liquidatie sloeg. Het had oorspronkelijk om een experimentele operatie moeten gaan; het was de bedoeling de voorbereidende werkzaamheden te controleren die dr. Viktor Brack, van de privékanselarij van de Führer, met gifgassen had ondernomen. Op basis van die informatie, die hij zowel van dr. Karl Brandt ${ }^{6}$ als van Ernst Damzog $^{7}$ had gekregen, ging W. Koppe ervan uit dat het niet ging om het doden van alle Joden, althans niet zij die konden werken - een bewering die nochtans niet wijst op enige terughoudendheid aangaande het idee om een groep mensen en masse te vermoorden. Dat bleek nog duidelijker toen hem tijdens zijn verhoor werd verweten dat hij op 3 mei 1942 een brief aan dr. Karl Brandt had gericht opdat het Sonderkommando Lange de tuberculeuze Polen een 'speciale behandeling' zou 


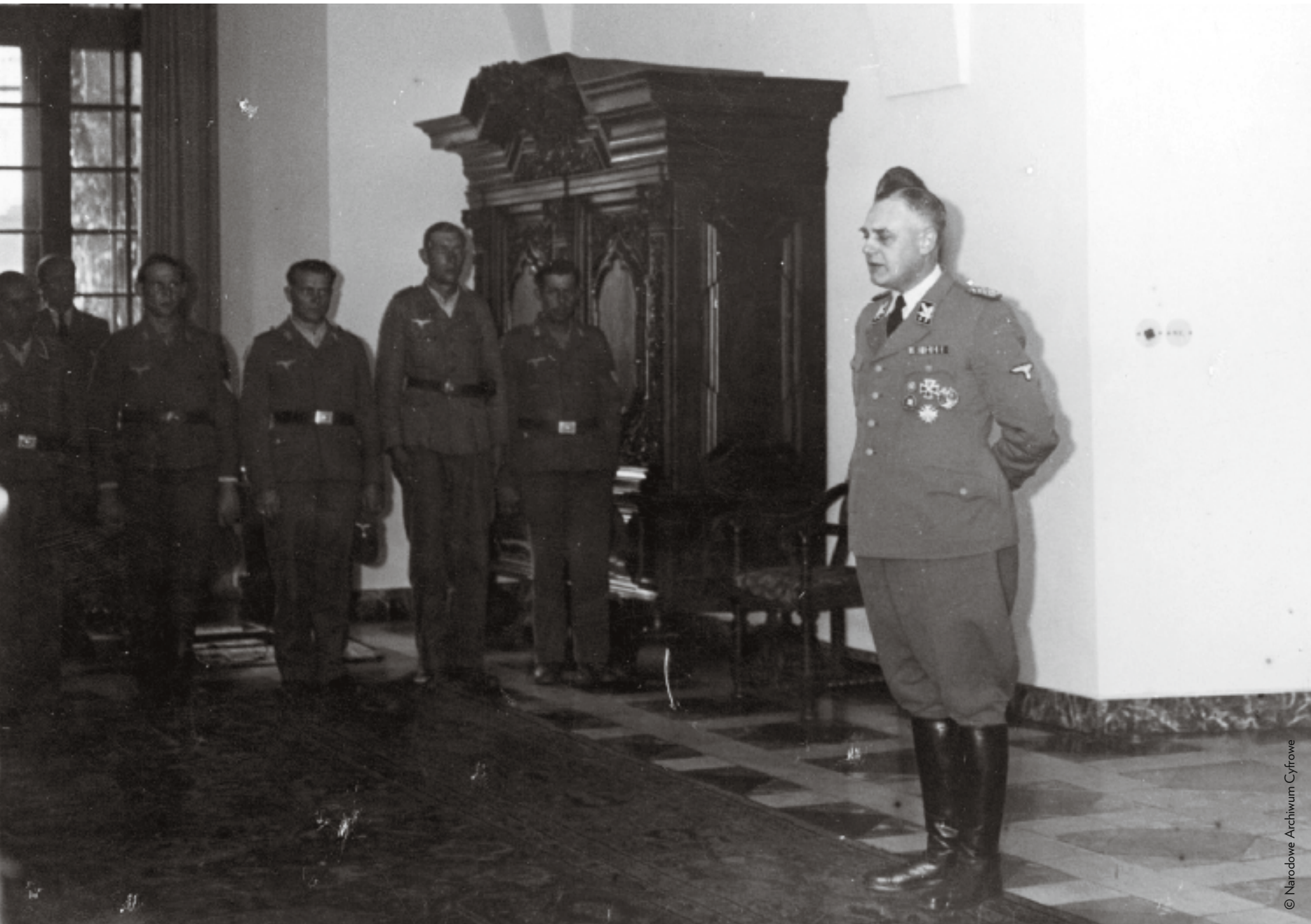

geven. Op die aanmerking antwoordde W. Koppe alleen dat hij had voorgesteld die mannen niet te doden, maar hen naar het Generaal-gouvernement te deporteren, omdat de executie van de zieke Polen volgens de Duitsers zou zijn neergekomen op marteling. Ook hier weer blijkt uit de verklaring van W. Koppe op generlei wijze een veroordeling van de moord of zelfs maar een oprecht teken van afkeuring.

Nadat hij de moordopdracht van het Sonderkommando had vernomen zou W. Koppe naar eigen zeggen toch een 'intelligente manier' hebben gezocht om de beslissing van het centrum tegen te werken. ${ }^{8}$ Zo zou hij contact hebben opgenomen met Artur Greiser om hem een plan voor te leggen waardoor de Joden voor de Duitse oorlogsinspanning zouden worden ingezet; op die manier zou hij dus hebben bepleit dat ze onmisbaar waren voor de economie, wat uiteindelijk hun terechtstelling had

_SS-Obergruppenführer Wilhelm Koppe spreekt de Duitse arbeiders toe op het koninklijk paleis van Warschau. Juni 1944

(8) Zie het proces-verbaal van het hoger vermelde verhoor van Wilhelm Koppe. 
Wilhelm Koppe en Josef Oberhauser versus de WestDuitse justitie: voorbeelden van een eerste vorm van revisionisme (vervolg)

\section{(9) Ibid.}

(10) De datum die Eichmann vermeldt, is te vroeg. Als hij toezag op een vergassingsoperatie, moet het bezoek iets later hebben plaatsgevonden, namelijk eind 1941 of begin 1942. moeten verhinderen. W. Koppe vermeldde vervolgens dat Artur Geiser dit 'plan' zou hebben aanvaard en dat beiden bij Göring een afspraak hadden aangevraagd om hem de details van hun project uit te leggen. Maar zodra ze in Berlijn waren aangekomen zouden ze zijn ontvangen door de baas (een burger) van diens generale staf, die zou hebben aangeraden de hun opgedragen taak te volbrengen en de zorg voor de bewapeningsindustrie aan de Reichsmarschall over te laten. Dat was meteen het einde van W. Koppes relaas over het mislukken van zijn zogezegde poging om te verhinderen dat het Sonderkommando Lange de Joden terechtstelde. ${ }^{9}$

Dit relaas, dat W. Koppe tijdens zijn verhoor in Bonn deed, lijkt ons bijzonder twijfelachtig, meer bepaald wat betreft zijn beklemtoning van het feit dat het Sonderkommando bevelen van Berlijn zou hebben gekregen, en niet van hemzelf. Berlijn lag inderdaad aan de basis van de bevelen en instructies die verband hielden met het plan om de Joden uit te roeien. Maar de sleutelfunctie van opperbevelhebber van de SS en de politie in de Warthegau, die Wilhelm Koppe van 9 oktober 1939 tot 9 november 1943 uitoefende, bleef de hoogste instantie in die administratieve regio. Wie die functie uitoefende, communiceerde en verspreidde het bevel, enerzijds naar de betrokken administratieve eenheden ter plaatse en anderzijds naar het speciale team dat was belast met het uitvoeren van de moordopdracht. Dat blijkt ook duidelijk uit het speurwerk van Ruth Bettina Birn, die onderzoek deed naar de instelling van opperbevelhebber van de SS en de politie, waarbij ze zich baseerde op heel wat concrete voorbeelden. Zo citeert ze, om haar stelling te staven, het derde deel van een van de eerste decreten, waarin de functie van opperbevelhebber van de SS en de politie in Breslau werd toevertrouwd aan Erich Von dem Bach-Zelewski. Die tekst stelt onomwonden dat die laatste via 'Sonderanweisung' (speciaal bevel) (Birn 1986, 11) nog andere opdrachten kreeg die bij zijn functie behoorden, waaruit blijkt dat die betrekking vanaf het begin was opgevat als een beslissende schakel tussen de nazistaat en de plaatselijke ambtenaren, onder wie later de uitvoerders van de Endlösung.

Desondanks bevestigt Adalbert Rückerl in zijn studie over de vernietigingskampen dat door het West-Duitse juridische onderzoek niet sluitend kon worden vastgesteld van wie en via welke instantie het Sonderkommando zijn bevelen kreeg (Rückerl 1979, 251). Toch noteert ook hij dat W. Koppe, A. Greiser, E. Damzog en A. Eichmann in Chełmno een aantal inspecties hielden. Eichmann met name werd 'in de herfst van 1941' naar het kamp gestuurd door Heinrich Müller, het hoofd van Bureau IV van het RSHA, met de opdracht hem een rapport te bezorgen over de aanvangsactiviteiten van het vernietigingskamp (Von Lang 1982, 71).$^{10}$ Ruth Bettina Birn stelt dan weer een zekere verslapping vast in de wijze waarop W. Koppe de functie van opperbevelhebber van de SS en de politie uitoefende. Terwijl hij het vernietigingskamp bleef superviseren zou hij evenwel de dienst van Ernst Damzog, inspecteur van de veiligheidspolitie, hebben omgevormd tot een commandobureau bevoegd voor alle met Chełmno gerelateerde kwesties (Birn, 1986, 181). 
Dit argument van Ruth Bettina Birn lijkt ons helemaal plausibel en in overeenstemming met de structuur van Chełmno. We willen preciseren dat de administratieve overheden van Posen en Litzmannstadt werden betrokken bij het functioneren van het eerste vernietigingskamp van de Endlösung (Kaczmarek, 2001, 29). Het gaat meer bepaald om het Duitse beheer van het Litzmannstadt-getto, onder leiding van Hans Biebow. Ze waren er niet alleen bij betrokken, maar waren ook aanwezig tijdens de terechtstelling die in het getto van Łódź zelf begon, dit in tegenstelling tot de andere vernietigingskampen. Die vaststelling gaat ook op voor de andere getto's in de Warthegau-stadjes. In Chełmno vond bijna geen selectie plaats, zelfs niet als het erop aankwam de groep Arbeitsjuden te versterken, waarvan de leden geregeld door het SS-Sonderkommando werden gefusilleerd. Vanuit de getto's vertrokken de vrachtwagens en treinen naar het vernietigingskamp in Chełmno met slachtoffers die allemaal naar de gaswagens werden gezonden. Wanneer het Sonderkommando de getalsterkte van de Arbeitsjuden wilde opvoeren, werden de Joden die tot die groep zouden behoren ook grotendeels met vrachtwagens gedeporteerd, van aan het getto tot in Chełmno.

Ondanks die actieve deelname van Duitse beheerders bleefW. Koppe de belangrijkste lokale gezagsdrager in het uitvoeren van de Endlösung in de Warthegau. Een eerste bewijs daarvan vormt een hem 'voorgelegd' document met zijn handtekening en vermelding van het Sonderkommando. Ondanks dit concrete bewijs trachtte W. Koppe tijdens zijn verhoren uit te leggen dat de documenten waren opgesteld door niet bijzonder snuggere ambtenaren en dat hij niet altijd de tijd had om de nodige correcties aan te brengen in de administratieve stukken. ${ }^{11}$

Naast dat door W. Koppe ondertekende document bevestigde een lid van het Sonderkommando Kulmhof tijdens een verhoor dat hij de opperbevelhebber van de SS en de politie van de Warthegau een keer in Chełmno had gezien. Dit lid kende W. Koppe goed en kon zich niet vergissen, want hij had de leider van het Sonderkommando Kulmhof vaak naar Posen en Litzmannstadt gebracht, waar die rapporten over de vernietigingskampen overbracht. ${ }^{12}$ Een andere wachter van het Wachkommando kon weliswaar de namen niet noemen van de hoge ambtenaren die Chełmno inspecteerden, maar nadat hij tijdens een verhoor diens oorlogsfoto had gezien, herkende hij wel W. Koppe. Hij verklaarde dat hij hem in Chełmno had gezien, ofwel in Eichstädt tijdens een verbroedering van het SS-Sonderkommando, of misschien tijdens een afscheidsfeestje in Warthbrücken, georganiseerd toen het vernietigingskamp een eerste maal werd opgedoekt. ${ }^{13}$

Maar de poging van de zoon van W. Koppe - die als diens advocaat druk had uitgeoefend op een getuige opdat die zijn oorspronkelijke verklaring zou wijzigen - vormt misschien het beste bewijs van zijn vaders schuld. Als SS-generaal en bevelhebber van de Ordnungspolizei in de Warthegau vanaf het begin van de oorlog tot halfweg 1942 had de bewuste getuige, Oskar K., eerder een verklaring afgelegd waarin hij
(11) Zie het proces-verbaal van het verhoor van Wilhelm Koppe.

(12) Zie het proces-verbaal van het verhoor van Walter Burmeister, een lid van het Sonderkommando Kulmhof, in Flensburg op 25 januari 1961 (Barch 162/3246, bladen 631638). In 1966 werd beslist dat Wilhelm Koppe niet in staat was de beraadslagingen bij te wonen, waarna zijn juridische vervolging werd stopgezet. Hij overleed acht jaar later.

(13) Zie het proces-verbaal van het verhoor van Wilhelm Heu, lid van het Wachkommando, in Meinerzhagen op 30 november en 1 december 1961 (Barch 162/3247, bladen 885-899). 
Wilhelm Koppe en Josef Oberhauser versus de WestDuitse justitie: voorbeelden van een eerste vorm van revisionisme (vervolg)
(14) Zie het proces-verbaal van het verhoor van Oskar K., generaal van de Ordnungspolizei. Hij werd op 25 maart 1960 in Starnberg als getuige verhoord door het kantoor van de procureur-generaal in Bonn (Barch 162/3245, bladen 459463).

(15) Zie het proces-verbaal van het getuigenverhoor van Oskar K. in Percha op 30 mei 1960 door het kantoor van de procureur van de republiek in Bonn (Barch 162/3245, bladen 470-472).

(16) Zie de verklaring onder ede van Oskar K. bij notaris Heribert Thallmair in Starnberg op 11 april 1960 (Barch 162/3245, bladen 464-467).
W. Koppe verantwoordelijk had gesteld: 'Zowel Koppe als Damzog waren vaak in Berlijn, bij Himmler en in het RSHA. Ze bespraken kort de relevante maatregelen en andere zaken; de gedetailleerde bevelen kwamen later van Koppe.14

In Himmlers professionele agenda wordt inderdaad tweemaal melding gemaakt van een dergelijk contact. In het bewuste document is eerst sprake van een onderhoud tussen W. Koppe en de Reichsführer-SS, op 4 september 1941 van de 21.30 tot 24.00 uur - twee weken voor de beslissing om de Joden uit het Reich te deporteren, of veeleer ze te vermoorden. Blijkens het uur van het onderhoud, dat hoogstwaarschijnlijk ging over de nieuwe terechtstellingsmethode en de eerste toepassing daarvan in de Warthegau, betreft het trouwens een onderwerp dat uitsluitend was bestemd voor een kleine groep kameraden (Witte 1999, 205).

In Himmlers professionele agenda is op 16 en 17 april 1942 trouwens sprake van een bezoek van de Reichsführer-SS aan de Warthegau, waar hij door A. Greiser en W. Koppe werd onthaald. De tweede dag van dat bezoek omvatte van 11.00 tot 12.00 uur een inspectie in Warthbrücken en Redern, met W. Koppe als enige begeleider. Het dorp Redern, op vijf kilometer van Warthbrücken, mocht voor de nazigezagsdragers dan een geslaagd voorbeeld zijn van de Duitse koloniseringspolitiek, behalve het inspecteren van het Chełmno-vernietigingskamp kon niets anders een bezoek aan Warthbrücken rechtvaardigen. Net als het comité van historici dat zich met het publiceren van Himmlers professionele agenda bezighield, gaan wij er dus van uit dat op het programma van 16 april 1942 'Warthbrücken' staat vermeld om de naam van het vernietigingskamp te verhullen. Onze hypothese wordt bevestigd door de middag van dezelfde dag, want opnieuw lunchte Himmler om 14.00 uur met de Führer om hem een uur later tijdens een privéonderhoud een rapport te overhandigen over het bezoek aan de Warthegau (Witte 1999, 398-400); zowel aangaande het veroveren van Lebensraum voor het Duitse volk als de uitroeiing van de Europese Joden functioneerde de Warthegau als het nationaalsocialistische laboratorium.

Toch ondertekende Oskar K. op 11 april 1960 een verklaring onder ede bij een notaris in Starnberg, op verzoek van de zoon van W. Koppe die hem twee dagen eerder thuis had opgezocht. Vervolgens moest de generaal zich bij de magistraten van het kantoor van de procureur-generaal in Bonn verantwoorden over het waarom van die bijkomende verklaring. Hij beweerde dat hij in zijn verklaring bij de notaris niet alle veranderingen had aanvaard die de zoon van W. Koppe voorstelde, maar toch is het getuigenis inhoudelijk aanzienlijk gewijzigd ${ }^{15}$ : 'Later vernam ik dat Heydrich zou zijn belast met de Endlösung van het Joodse vraagstuk; het is mogelijk dat de [SS-]Sonderkommando's zijn verlengstuk waren en hun bevelen rechtstreeks van het RSHA kregen.' ${ }^{, 16}$

In deze nieuwe versie, onderschreven door Oskar K., werd niet alleen de werkelijke functie van W. Koppe in de Warthegau verdonkeremaand, maar veranderde 
de ervaring van een getuige in een relaas uit de tweede hand. Op die manier werd de commandant van de Ordnungspolizei in de Warthegau, die volgens het eerste verhoor op 25 maart 1960 bevelen kreeg van W. Koppe, na de verklaring van 11 april 1960 een figuur die zich buiten het organisatieschema bevond en pas verscheidene jaren na de oorlog van het bestaan van de Endlösung zou hebben gehoord.

Laten we ten slotte het organisatieschema van de nationaalsocialistische administratie bestuderen, zoals dat door de West-Duitse magistraten werd opgesteld in het raam van het juridische onderzoek aangaande Chełmno. We kunnen vaststellen dat de magistraten, specifiek wat de streek van de Warthegau betreft, vier bevelsstructuren onderscheidden waarlangs de bevelen en instructies binnen het bureaucratische apparaat circuleerden: Sicherheitspolizei, politie, administratie en RSHA. De functie van opperbevelhebber van de SS en de politie verschijnt in de bevelsstructuur van de Sicherheitspolizei, waar ze onder het directe gezag staat van Himmler, de Reichsführer-SS en het hoofd van de Duitse politie. Nog altijd binnen dezelfde bevelsstructuur blijft de SS’er die deze functie uitoefent de hiërarchische overste van de inspecteur van de Sicherheitspolizei en de veiligheidsdienst, en ook (op een lager niveau in de bevelsstructuur) van de staats- en gerechtelijke politie. Alleen de Reichsstatthalter (gouverneur van het Reich), die in principe ressorteert onder de
_ Fundamenten van het kasteel dat tussen 1941 en 1943 gebruikt werd door het SS Sonderkommando van Chełmno.

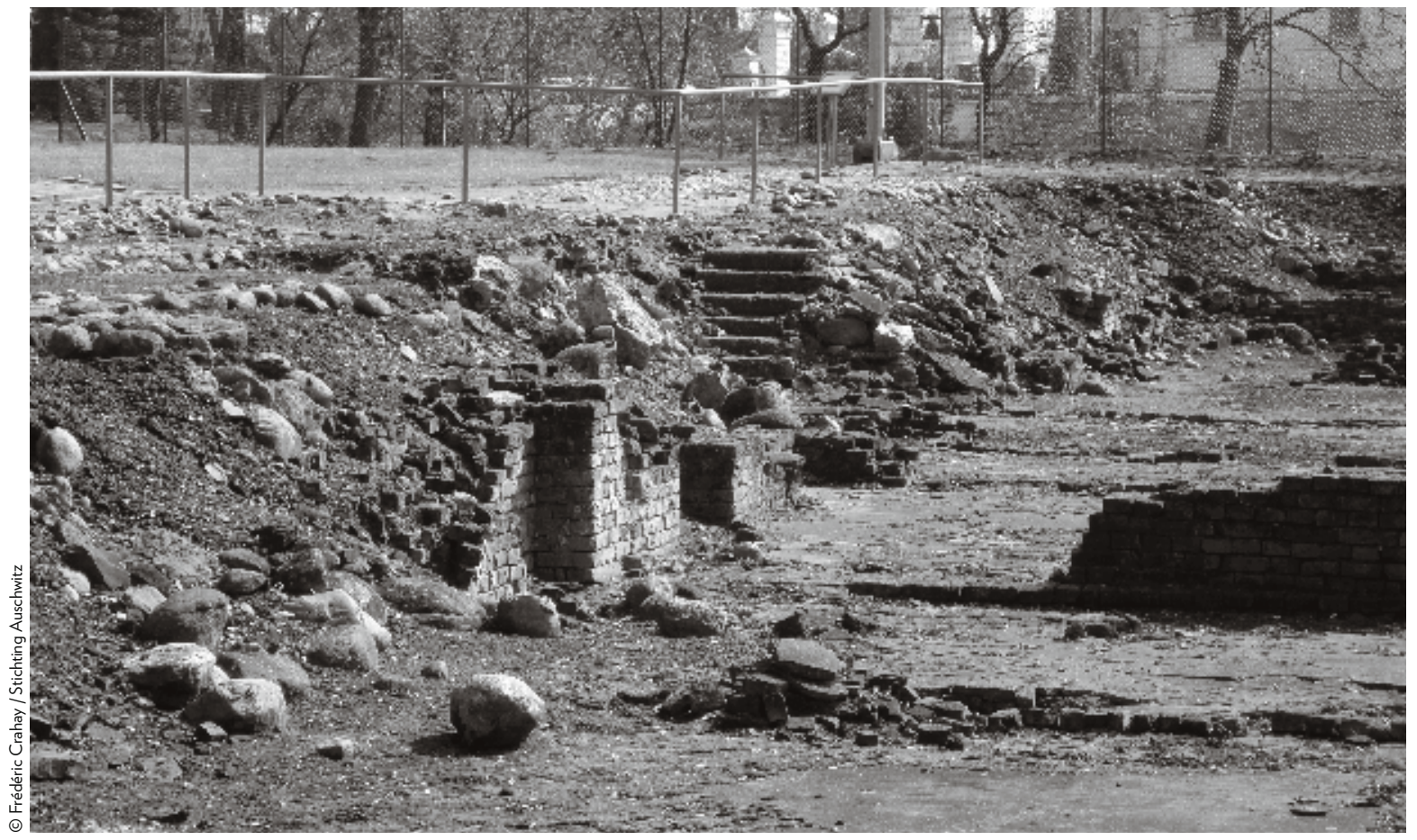


Wilhelm Koppe en Josef Oberhauser versus de WestDuitse justitie: voorbeelden van een eerste vorm van revisionisme (vervolg)

_ Joseph Oberhauser

(17) BA Ludwigsburg, Łódź, 203 AR-Z 69a/59, volume 3, blad 570. bevelsstructuur van de administratie en in direct contact staat met de regering van het Reich, onderhoudt in de bevelsstructuur van het RSHA een wederkerige relatie met het kantoor van de opperbevelhebber van de SS en de politie. Maar dit is veeleer een uitzondering die verband houdt met de figuur van Artur Greiser, de gouverneur van het Wartheland, die vooral bekendstond om zijn rabiate antisemitisme en zijn langdurige inzet voor de nationaalsocialistische zaak. ${ }^{17}$

Het probleem is dus de verwarring over de wijze waarop informatie circuleert binnen de bureaucratie van het Derde Rijk, als gevolg van de verschillende bevelsstructuren. Hoe inderdaad verklaren dat het RSHA, dat net als de opperbevelhebber van de SS en de politie onder het directe gezag van Himmler staat, met die instantie geen enkele relatie onderhoudt, hoewel het in de bevelsstructuur van de Sicherheitspolizei optreedt als de hiërarchische overste van de inspecteur van de Sicherheitspolizei, de Staatspolizei en de Kriminalpolizei? In werkelijkheid hield het RSHA zich hoofdzakelijk bezig met technische kwesties betreffende het gebruik van de gaswagens in de Warthegau, terwijl de opperbevelhebber van de SS en de politie Himmler in de streek vertegenwoordigde; hij gaf direct bevelen en instructies door en zag toe op het uitvoeren ervan.

Josef Oberhauser, die Christian Wirth tijdens diens hele moordmissie in het raam van Aktion Reinhard vergezelde, levert een tweede voorbeeld van een revisionistische strategie ten overstaan van de onderzoeksrechter. Toen C. Wirth het kamp Bełżec leidde, vervulde Josef Oberhauser aan zijn zijde al de taak van vertegenwoordiger van de bevelhebber. En na diens benoeming tot inspecteur van de $S S$-Sonderkommando's van Aktion Reinhard volgde hij Wirth naar Lublin om er zijn adjudant te worden.

Josef Oberhauser werd in 1915 geboren in München en begon als 


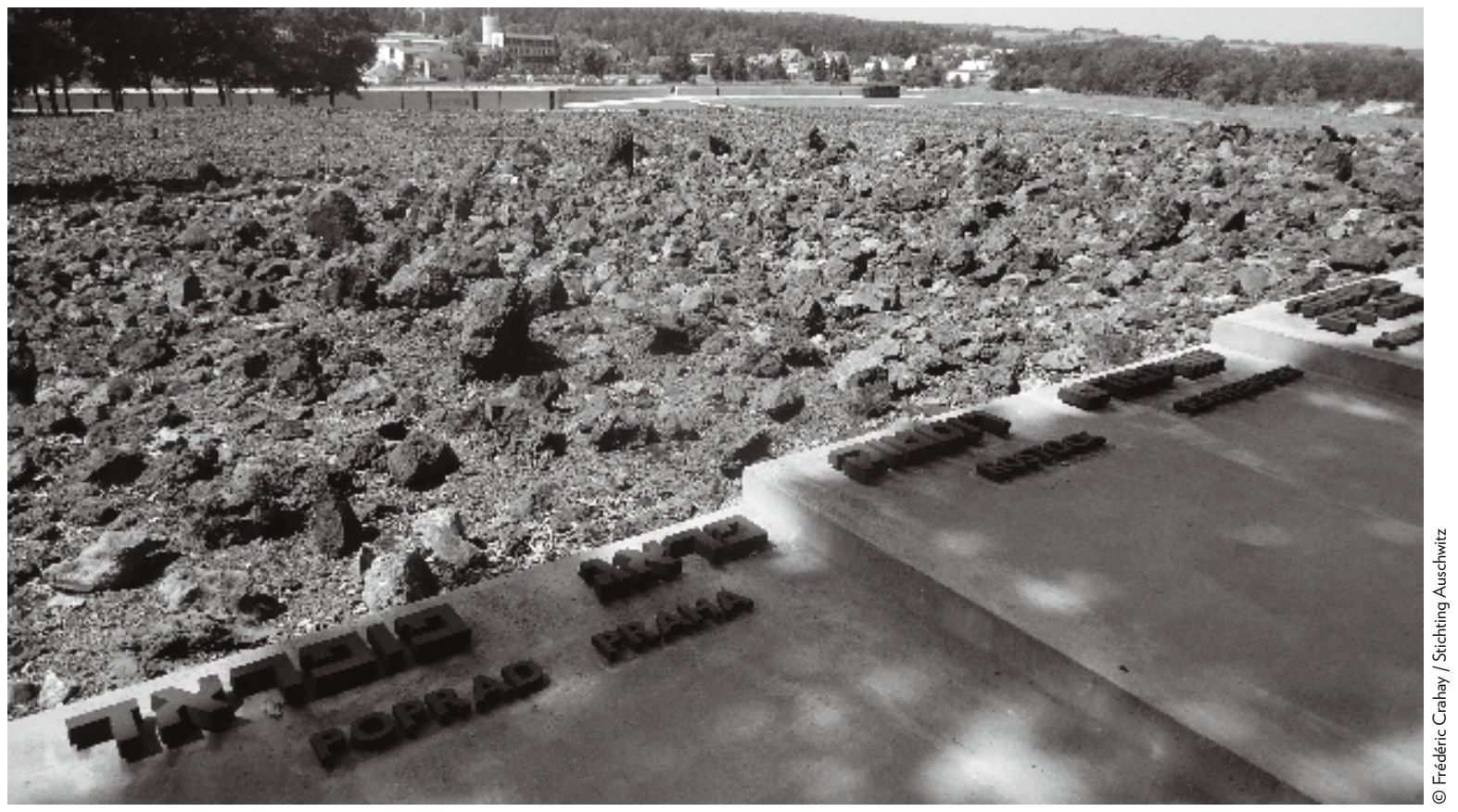

landarbeider te werken nadat hij de acht jaar Volksschule had beëindigd. Na zijn militaire dienst (1934-1935) bood hij zich vrijwillig aan voor de SS-Verfügunstruppe, vanwaar hij kort voor de oorlog werd toegevoegd aan de Leibstandarte Adolf Hitler in Berlin-Lichterfelde. De eenheid waar hij deel van uitmaakte had meegewerkt aan de Poolse campagne. Maar zijn betrokkenheid bij de uitroeiingspolitiek van de nazi's begon toen hij omstreeks Kerstmis 1939 werd ingedeeld bij het euthanasiecentrum in Grafeneck. Josef Oberhauser bleef er ongeveer drie maanden en daarna werd hij door Aktion T4 naar de instituten van Brandenburg en Bernburg gestuurd. Vervolgens was er zijn opdracht in het raam van Aktion Reinhard. In het najaar van 1941 werd hij overgeplaatst naar het kantoor van het hoofd van de SS en de politie in Lublin, waar hij een van de eerste leden was van het nieuwe speciale team. ${ }^{18}$

Op het einde van de oorlog werd hij door Britse troepen gearresteerd en opgesloten in een krijgsgevangenkamp, maar hij slaagde erin te ontsnappen. In 1948 werd hij een tweede keer opgepakt, ditmaal door de Russen, toen hij in het geheim van de Amerikaanse naar de Russische bezettingszone trachtte over te steken om een oorlogskameraad te bezoeken.

Vervolgens werd Josef Oberhauser op 24 september 1948 door de arrondissementsrechtbank in Maagdenburg veroordeeld tot vijftien jaar opsluiting. Die straf werd uitgesproken door de Russen wegens zijn deelname aan het euthanasieprogramma, lidmaatschap van de Waffen-SS en zijn activiteiten tegen Russische en Poolse verzetsstrijders; op geen enkele manier was daarbij sprake van zijn betrok-

(18) Zie het proces-verbaal van het verhoor van Josef Oberhauser in München op 15 september 1960 door het regionale kantoor van de Beierse gerechtelijke politie (Barch 162/3169, bladen 1036-1040). 
Wilhelm Koppe en Josef Oberhauser versus de WestDuitse justitie: voorbeelden van een eerste vorm van revisionisme (vervolg)
(19) Zie het proces-verbaal van het verhoor van Josef Oberhauser in München op 26 februari 1960 door het parket van de arrondissementsrechtbank in München I (Barch 162/3167, volume 4, bladen 656-660).

(20) lbid.

(21) Zie het proces-verbaal van het verhoor van Josef Oberhauser in München op 20 april 1960 door de onderzoeksrechter van de arrondissementsrechtbank in München I (Barch 162/3167, bladen 763-765). kenheid bij misdaden in het raam van Aktion Reinhard. Desondanks kreeg hij in april 1956 amnestie, net als andere Duitse oorlogsmisdadigers in Russische gevangenschap en nog voor hij zijn straf volledig had uitgezeten. Het betrof een Russische beslissing naar aanleiding van een bezoek dat Konrad Adenauer aan Moskou bracht. ${ }^{19}$

Na zijn terugkeer naar de Duitse Bondsrepubliek vestigde Josef Oberhauser zich in München. Hij ging er als kelner in een café werken tot hij in februari 1960 werd aangehouden in het raam van het juridische onderzoek naar de nazimisdaden in het Bełżec-kamp.

Tijdens de eerste verhoren ontkende Josef Oberhauser categorisch dat hij deel had uitgemaakt van het team van Aktion Reinhard. In zijn eerste versie van de feiten bleef zijn taak beperkt tot het opleiden van eenheden Oekraïners en Volksdeutsche. Hij gaf wel toe op de hoogte te zijn geweest van het bestaan van het Bełżec-kamp, maar beweerde dat hij er nooit een voet had gezet. Hij zou één enkele keer het transport van een dertigtal oude Wehrmacht-barakken hebben begeleid tot aan de poort van het kamp, maar zou niet naar binnen zijn gegaan. Volgens zijn relaas zou hij geen toestemming hebben gehad om binnen te treden in de rechthoekige ruimte, die streng was afgescheiden van de rest; in tegenstelling tot andere uitroeiingskampen omvatte dit vernietigingskamp ook enkele gewone plekken van het dorp Bełżec. ${ }^{20}$

Tijdens een tweede verhoor, twee maand na het eerste, stelde Josef Oberhauser zijn relaas bij. Hij gaf toe dat hij tweemaal in het Bełżec-kamp naar binnen ging, maar benadrukte dat dit gebeurde voor het een uitroeiingskamp werd. De reden van die omslag is ongetwijfeld het feit dat oud-leden van de SS-Sonderkommando's gelijkluidende verklaringen aflegden waarin melding werd gemaakt van Josef Oberhausers aanwezigheid in Bełżec. Daardoor moest hij zijn verhaal aanpassen en hij rechtvaardigde zijn verblijven in het kamp door middel van specifieke opdrachten. De eerste daarvan werd hem toevertrouwd door het kantoor van de opperbevelhebber van de SS en de politie in Lublin: in december 1941 zou hij proviand voor tien dagen hebben moeten afleveren, bestemd voor het team van Oekraïense wachten in Bełżec. Vervolgens zou hij in februari of begin maart 1942 voor de tweede maal in het kamp hebben verbleven. Ditmaal zou hij ermee belast zijn een contingent van dertig Oekraïense wachten naar Bełżec te brengen en weer proviand voor tien dagen te leveren. ${ }^{21}$

Na de eerste verhoren en vooral door het ontbreken van verklaringen vanwege Bełżec-overlevenden, slaagden de West-Duitse magistraten er niet in een onderzoeksdossier samen te stellen dat tot een proces had kunnen leiden. In augustus 1960 werd Josef Oberhauser vrijgelaten uit de gevangenis van München-Neudeck, waar hij sinds februari 1960 in voorhechtenis was. Hij kon opnieuw aan de slag als kelner in hetzelfde café. In Shoah zit een korte scène waarin je Josef Oberhauser in 
dat café aan het werk kunt zien, maar als Claude Lanzmann hem vraagt of hij zich Bełżec kan herinneren, doet hij er het zwijgen toe.

Pas in december 1962 gaf Josef Oberhauser uiteindelijk toe dat hij deel had uitgemaakt van het Bełżec-kamp. Maar zijn relaas stemde nog altijd niet overeen met de werkelijkheid. Hij stelde dat hij vanaf Kerstmis 1941 wel degelijk een ondergeschikte was geweest van Christian Wirth, de bevelhebber van het vernietigingskamp, maar hij zou alleen het contact hebben verzekerd tussen die laatste en het kantoor van Globocnik. Dat zou betekenen dat zijn taak beperkt was gebleven tot het overbrengen van bouwmaterialen tussen Lublin en Bełżec, naast het begeleiden van de teams van Oekraïense wachten. Nog altijd volgens hetzelfde twijfelachtige relaas zou de functie van vertegenwoordiger van Christian Wirth - die hem door meerdere oud-leden
_ Het bos van Rzuchów vlak bij Chełmno. Bij de hertekening van het memoriaal in 2015 werd rekening gehouden met recente wetenschappelijke ontdekkingen.

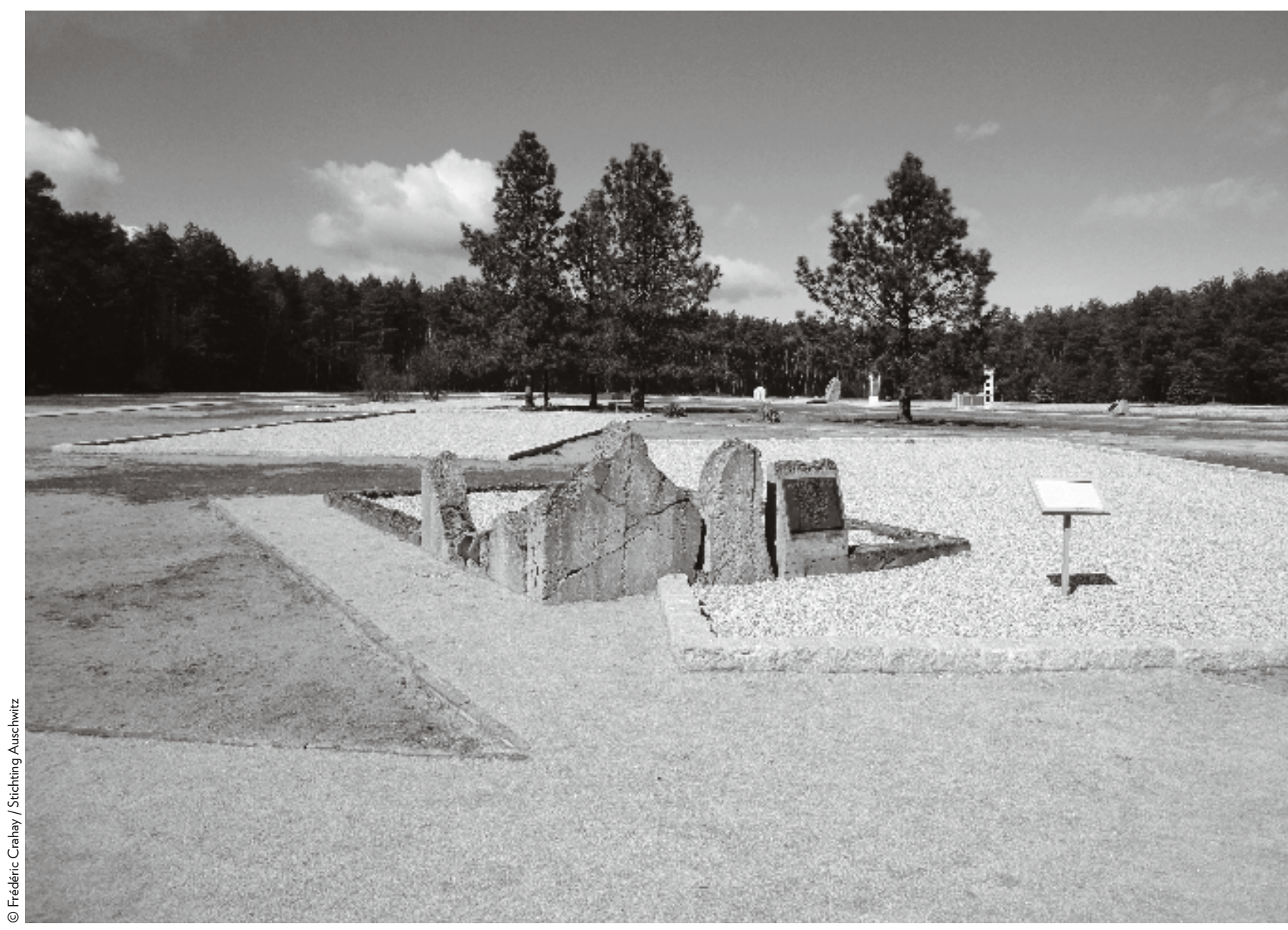


Wilhelm Koppe en Josef Oberhauser versus de WestDuitse justitie: voorbeelden van een eerste vorm van revisionisme (vervolg)
(22) Zie het proces-verbaal van het verhoor van Josef Oberhauser in München op 12 en 14 december 1962 door de eerste procureur (Barch 162/3172, bladen 1678-1688).

(23) Zie het proces-verbaal van het verhoor van Josef Oberhauser in München op 15 september 1960.

(24) Zie het proces-verbaal van het verhoor van Willy Häusler in Bremerhaven op 28 november 1962 door het parket van de arrondissementsrechtbank in München I (Barch 162/3171, bladen 1655-1659).

(25) Zie het proces-verbaal van het verhoor van Karl Schluch in Kleve op 10, 11 en 12 november 1961 door het regionale kantoor van de Beierse gerechtelijke politie (Barch 162/3171, bladen 1503-1525).

(26) Zie het proces-verbaal van het verhoor van Josef Oberhauser in München op 13 december 1962 door de eerste procureur (Barch 162/3172, bladen 1689-1693). van SS-Sonderkommando's werd toegeschreven - in werkelijkheid door Gottfried Schwarz zijn uitgeoefend. Maar die was de vertegenwoordiger van Gottlieb Hering, de tweede bevelhebber van Bełżec. Josef Oberhauser gaf wel toe een aantal keer bevelen te hebben gegeven aan het Duitse personeel van het vernietigingskamp, maar dit zou alleen zijn gebeurd op uitdrukkelijke richtlijn van Christian Wirth. ${ }^{22}$

Josef Oberhauser deelde trouwens foutieve informatie mee over de verschillende perioden waarin hij in het Bełżec-kamp verbleef. Hij verklaarde meer bepaald dat hij vanwege het kantoor van Globocnik in het najaar van 1941 de opdracht had gekregen om in Bełżec (het dorp) oorlogsmateriaal te verzamelen dat zich verspreid langs de oude Duits-Russische demarcatielijn bevond en dit achtergelaten materiaal vervolgens naar Lublin te verzenden. Het is zeer aannemelijk dat Josef Oberhauser inderdaad het bevel voor een dergelijke opdacht kreeg. Maar ze duurde helemaal niet, zoals hij tijdens een van zijn verhoren had geopperd, tot in de zomer van 1942, het begin (weer volgens eigen zeggen) van zijn vermeende aanstelling als bewaker van de Duitse wapenfabrieken in Lublin. Hoewel hij het ontkende, was Josef Oberhauser in die periode aangesteld als adjudant van Christian Wirth, die toen was benoemd tot inspecteur van de SS-Sonderkommando's van Aktion Reinhard. Op basis van ondervragingen van oud-leden van de $S S$-Sonderkommando's toonden de West-Duitse magistraten aan dat hij op het einde van de zomer van 1942 Globocnik had vergezeld bij een bezoek aan Treblinka, waarop Josef Oberhauser zich nogmaals verdedigde door te verklaren dat hij toen uitsluitend als escorte aan de inspectiecommissie was toegewezen. ${ }^{23}$

Toch zijn er heel wat aanwijzingen die zijn directe betrokkenheid bij Aktion Reinhard aantonen. Willy Häusler, een lid van het kantoor in Lublin, preciseerde meer bepaald dat hij administratieve brieven in een dossier moest verzamelen om ze bij afwezigheid van Christian Wirth door Josef Oberhauser te laten ondertekenen; de handtekening telde voor de West-Duitse magistraten als het uitoefenen van een beslissingsbevoegdheid en het beschikken over bevelvoerend gezag. ${ }^{24}$ Maar zelfs zonder die bevoegdheid volstaat het deel uitmaken van het personeel in Bełżec ruimschoots om de schuld van een verdachte aan te tonen, zoals Karl Schluch, een lid van dat team, beklemtoonde: 'Als niemand van ons kan worden vrijgepleit, dan Josef Oberhauser nog veel minder [dan wie ook]... Het Bełżec-kamp had uiteindelijk maar één doel en wat zou Oberhauser daar anders hebben gedaan en waarom zou hij zijn bevorderd?'25

Pas in december 1962, tijdens een nieuw verhoor, gaf Josef Oberhauser ten slotte toe dat hij foutieve informatie had verstrekt over zijn functie gedurende de oorlogsjaren. Hij rechtvaardigde zijn houding door de overtuiging dat hij van de nog levende leden van de Einsatz Reinhard diegene was met de hoogste graad. Hij was toen de overtuiging toegedaan dat hij door zelfs maar een minieme deelname aan die operatie verantwoordelijk zou worden gesteld voor de hele moorddadige onderneming. ${ }^{26}$ 
Door de twee voorbeelden die we hierboven hebben geschetst wordt duidelijk dat dankzij de getuigenissen van nauwelijks vijf overlevenden, drie van Chełmno en twee van Bełżec, de oud-leden van de SS-Sonderkommando's hun vervalste versie van de nazibezettingsjaren in Polen niet langer konden volhouden. Door die getuigenissen verraadden de verdachten zichzelf, wat ook leidde tot vooruitgang in de moeizame vooronderzoeken in West-Duitsland. Maar door toedoen van die enkele overlevenden moesten ook en vooral de verdachten hun vervalste versie aanpassen. Hun negationistische houding bogen ze om tot een vorm van revisionisme, waarbij ze de realiteit van de volkerenmoord trachtten te verzoenen met een strategie die hen toeliet zichzelf vrij te pleiten.

Vertaling: Gorik de Henau

\section{BIBLIOGRAFIE}

- Ruth Bettina Birn, Die Höheren SS- und Polizeiführer. Himmlers Vertreter im Reich und in den besetzten Gebieten, Düsseldorf: Droste Verlag, 1986.

- Marian Kaczmarek, 'Die nationalsozialistischen Pläne für die Vernichtung der Juden im "Reichsgau

Wartheland"', in Manfred Struck (red.), Chełmno/Kulmhof. Ein vergessener Ort des Holocaust?, Bonn-Berlijn: Gegen Vergessen - Für Demokratie, 2001, 15-30.

- Adalbert Rückerl, Nationalsozialistische Vernichtungslager im Spiegel deutscher Strafprozesse. Bełżec, Sobibór, Treblinka, Chełmno, München: Deutscher Taschenbuch Verlag, 1979.

- Jochen Von Lang, Das Eichmann-Protokoll. Tonbandaufzeichnungen der israelischen Verhöre, Berlijn: Severin und Siedler, 1982.

- Peter Witte, Der Dienstkalender Heinrich Himmlers 1941/42, Hamburg: Hans Christians Verlag, 1999. 